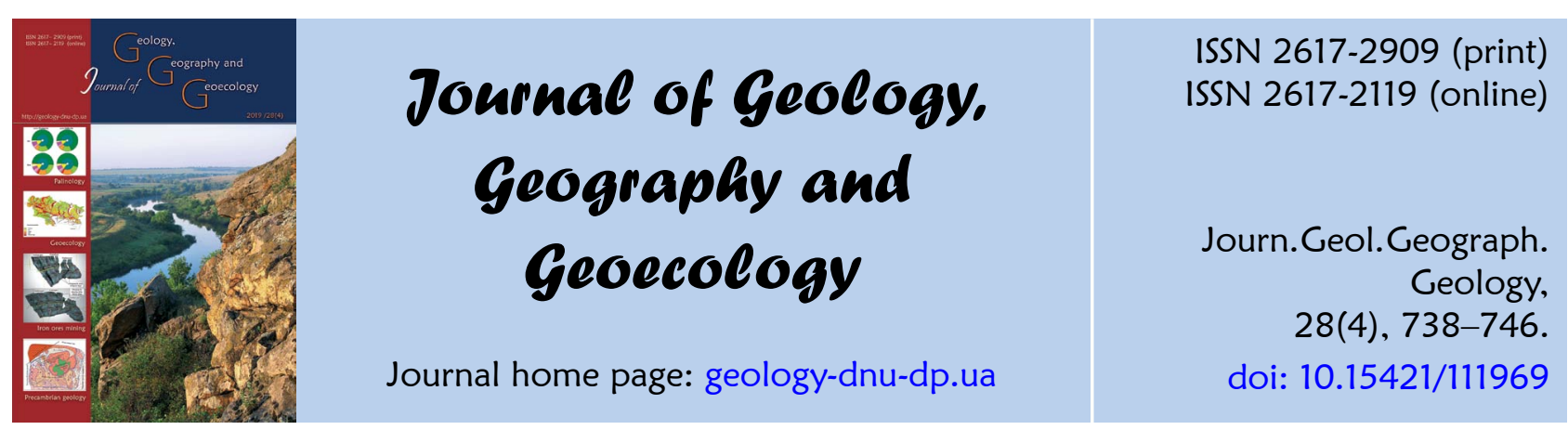

Vasyl M. Savosko, Yuriy V. Lykholat, Yulia V. Bielyk, Tetiana Y. Lykholat

Journ. Geol. Geograph. Geoecology, 28(4), 738-746.

\title{
Ecological and geological determination of the initial pedogenesis on devastated lands in the Kryvyi Rih Iron Mining \& Metallurgical District (Ukraine)
}

\author{
Vasyl M.Savosko', Yuriy V. Lykholat ${ }^{2}$, Yulia V. Bielyk², Tetiana Y. Lykholat ${ }^{2}$ \\ ${ }^{1}$ Kryvyi Rih State Pedagogical University, Kryvyi Rih, Ukraine, savosko1970@gmail.com \\ ${ }^{2}$ Oles Honchar Dnipro National University, Dnipro, Ukraine
}

Received: 03.06 .2019
Received in revised form: 12.06.2019
Accepted: 10.11 .2019 experimental sites which represent the main varieties of devastated land in the Kryvyi Rih Iron Mining and Metallurgical District (Central Ukraine): (i) waste rock dumps of old iron mines (old name "Forges"), (ii) tailing storage facility of underground iron mines, (iii) waste rock dumps of the Iron Ore Mining and Dressing Plant, (iv) waste rock dumps of the Granite Quarry Plant. It was established that on the devastated lands in Kryvyi Rih District, the initial soil formation occurs in very difficult conditions. Therefore, over 25100 years only very primitive soils were formed. The following features are inherent to them: (1) primitive soil profile (thickness 10-100 mm), (2) low levels of soil organic substance content (9.5-11.5\%), (3) alkaline indicators of the soil solution $\left(\mathrm{pH}_{\mathrm{H} 2 \mathrm{O}}-8.08\right.$ $\left.8.92, \mathrm{pH}_{\mathrm{KCl}}-7.42-8.23\right)$, (4) low levels of cation exchange capacity (6.34-8.47 mMol /100 g). By results of correlation calculations, among the factors of soil formation time (duration of soil formation) and input of plant ash elements' fall are characterized by the maximum number of statistically significant correlation coefficients and their numerical values. In terms of chemical composition of the technosol, the values of organic matter content and exchangeable acidity $\left(\mathrm{pH}_{\mathrm{KC}}\right)$ were the most predictable soil formation factors. Generally physical / chemical characteristics of geological rocks (as parent material) and time were the two most important factors in determining the initial pedogenesis on devastated lands in the Kryvyi Rih Iron Mining \& Metallurgical District (Ukraine).

Keywords: devastated land, initial pedogenesis, technosol, embryozems, Kryvyi Rih Basin

\section{Екологічна та геологічна зумовленість ініціального педогенезу на девастованих землях Криворізького гірничо-металургійного регіону (Україна)}

\author{
В. Савосько ${ }^{1}$, Ю. Лихолат ${ }^{2}$ Ю.Бєлік ${ }^{2}$, Т. Лихолат ${ }^{2}$
}

\section{${ }^{1}$ Криворізький державний педагогічний університет, Кривий Piг, Україна, savosko1970@gmail.com 2 Дніпровський національний університет імені Олеся Гончара, Дніпро, Украӥна}

\begin{abstract}
Анотація. Дуже актуальною проблемою сьогодення залишається припинення негативних впливів на довкілля людини та повернення у практичне використання територій девастованих земель. У зв'язку з цим важливим є з'ясування провідних закономірностей первинного грунтоутворення на теренах цих техногенних новоутворень. Умови початкового грунтоутворення було проаналізовано на 19 дослідних ділянках, які репрезентують основні різновиди девастованих земель Криворізького гірничо-металургійного району (Дніпропетровська область, Центральна Україна): (i) породні відвали старих залізних копалень (старі назви «кавалери»), (ii) хвостосховища залізорудних шахт, (iii) породні відвали залізорудного гірничо-збагачувального комбінату, (iv) породні відвали гранітного кар'єру. Встановлено, що на девастованих землях Криворізького гірничометалургійного району початкове грунтоутворення відбувається в дуже складних умовах. Тому за 25-100 років утворилися лише дуже примітивні грунти. Для них притаманно: (1) малопотужний грунтовий профіль (товщина 10-100 мм), (2) низький вміст органічної речовини грунту $(9,5-11,5 \%),(3)$ лужні показники грунтового розчину $\left(\mathrm{pH}_{\mathrm{H} 2 \mathrm{O}}-8,08-8,92, \mathrm{pH}_{\mathrm{KCl}}-7,42-8,23\right),(4)$ низькі рівні ємності катіонного обміну (6,34-8,47 ммоль / 100 г). Ці молоді грунти девастованих земель Криворізького гірничометалургійного району можна класифікувати як Сполік Техносол (за даними Всесвітньої референтної бази для грунтових ресурсів) або Ембріоземи (згідно з українською системою класифікації). Серед факторів формування грунту час (тривалість формування грунту) та надходження зольних елементів рослин характеризується максимальною кількістю статистично значущих коефіцієнтів кореляції та їх числовими значеннями. Результати кореляційних розрахунків довели, що серед показників
\end{abstract}


хімічного складу Техносолу значення вмісту органічної речовини та обмінної кислотності $\left(\mathrm{pH}_{\text {кс }}\right)$ були найбільш передбачуваними. Загалом, фізико-хімічні характеристики геологічних порід (як материнського матеріалу для грунтоутворення) та час були двома найважливішими чинниками, що детермінують початковий педогенез на девастованих Криворізького гірничометалургійного району.

Ключові слова: девастовані землі, ініціальний педогенез, пехносол, ембріозем, Криворіжжя

Introduction. Devastated lands are a widespread phenomenon in all industrial regions of the world, Europe and Ukraine. Their area reaches impressive values. In particular, in Ukraine the area of devastated lands is hundreds of thousands of hectares, in the Dnipro industrial region it is more than 50 thousand hectares, in the Kryvyi Rih Iron Mining \& Metallurgical District (Kryvorizhya) more than 20 thousand hectares (Antrop, 2006; Cortina-Segarra et al, 2016; Malahov, 2003).

Devastated land negatively affects the quality of human life. They are a source of additional pollution of atmospheric air, groundwater and soils. In addition, they negatively affect the microclimate and the aesthetics of industrial regions (Aronson \& Alexander, 2013; Hlava et al, 2015; Malahov, 2009).

However, in our country virtually no large-scale and complete restoration of the devastated lands in accordance with the current legislation and the available scientific achievements has been carried out. The main reason for this is the lack of funds and non-compliance by industry with current legislation (Berger et al, 2011; Demidov et al, 2013 Kumar, 2013; Mazur et al, 2015; Savosko, 2011a).

As a result of this situation, the land devastated has been left entirely neglected. On their territories there are spontaneous processes of self-healing of the vegetative cover and the processes of initial soil formation (initial pedogenesis) proceed gradually. An important component of such vegetation is trees and shrubs, which have a positive effect on the state of the environment in industrial regions (Lykholat et al, 2016a; Lykholat et al, 2016b; Savosko \& Tovstolyak, 2017; Savosko et al, 2018; Tereschenko, 1992). However, the processes of self-healing of the film of life on devastated lands are exceedingly slow sometimes taking hundreds of years. Therefore, it is very important to identify the patterns of initial soil formation and to find out the leading factors of this process (Resulović \& Čustović, 2007; Savosko, 2011a; Savosko et al, 2010; Savosko, 2011b).

On the devastated lands of the Kryvyi Rih Iron Mining \& Metallurgical District the elucidation of the laws of ecological and geological processes of initial pedogenesis has fundamental scientific and practical significance. The consideration of this problem was chosen for the purpose of our work.

Materials and methods. The materials of our research were the results of the surveys conducted by us during
2006-2018 on the devastated lands in the Kryvyi Rih Iron Mining \& Metallurgical District (Figure 1).

The objects of research were the primitive soils from the devastated lands, which appeared on Kryvyi Rih during the twentieth century: 1) waste rock dumps of old iron mines (old name "Forges"), 2) tailing storage facility of underground iron mines, 3) waste rock dumps of the Iron Ore Mining and Dressing Plant, 4) waste rock dumps of the Granite Quarry Plant.

Methods of research - classical field and laboratory research by soil science, agrochemistry and biogeochemistry (DSTU-ISO 10381-8:2006; DSTUISO 10390:2001; DSTU-ISO 10694-2001; DSTUISO 11664:2006; DSTU-ISO 11260:2001; DSTU-ISO 11664:2006).

The obtained results of researches were processed by classical mathematical statistical methods at the level of significance $\mathrm{P}<0,05$ (Lakin, 1990; MCdonald, 2014).

Results and discussion. The pedogenetic features on devastated lands. In natural conditions, soils, soil properties and soil formation are strongly affected by: 1) parent material, 2) vegetation, 3) climate, 4) topography, 4) man and 5) time (Jenny, 1994; Breemen, \& Buurman, 2003). Therefore, to understand the pedogenetic features on the devastated lands, at first it is necessary to analyze the actions of soil formation factors under these conditions.

Parent material. Initial soil formation on devastated lands in the Kryvyi Rih area occurs on different rocks. According to the estimation technique, rocks on the devastated lands are organized into three groups: 1) highly favourable to initial soil formation, 2) moderately favourable to initial soil formation, 3) minimally favourable to initial soil formation. The rocks which are highly favourable to initial soil formation are represented mainly by loess and loesslike loams, as well as by loams and sandy loams from the sedimentary cover. The rocks that are moderately favourable to initial soil formation are represented by medium clay, heavy clay from the sedimentary cover, as well as finely fractional (less than 10 $\mathrm{mm}$ ) rocky deposits of different genesis. The rocks which are most favourable to initial soil formation are following: large-fragment rocky rocks (over 10 $\mathrm{mm}$ ), phytotoxic rocks by various genesis, as well as waste from the mining and metallurgical industry. It is important to note that on the devastated lands in 


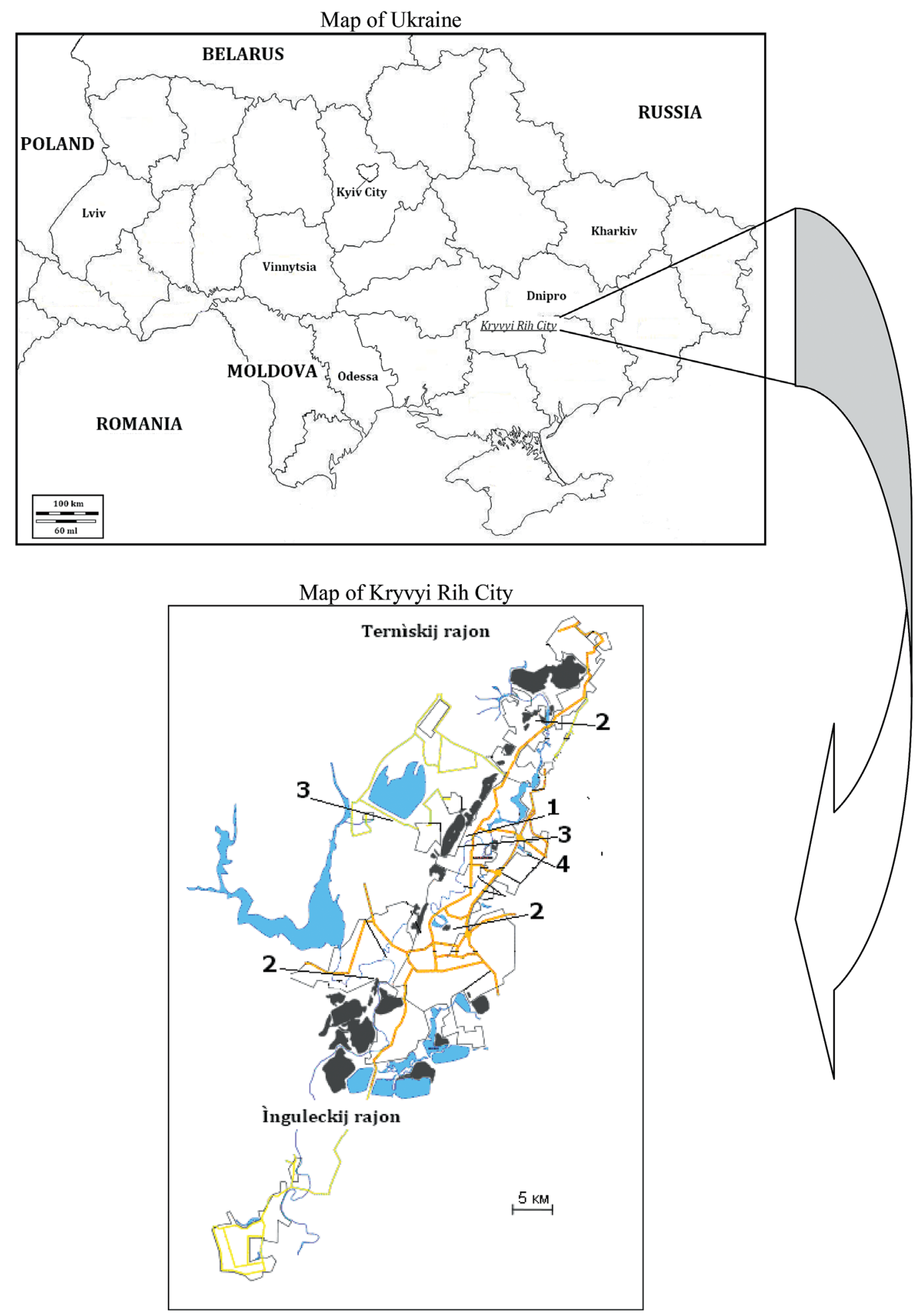

Fig. 1. Location of study areas

1 - waste rock dumps of old iron mines (old name "Forges"), 2 - tailing storage facility of underground iron mines, 3 - waste rock dumps of the Iron Ore Mining and Dressing Plant, 4 - waste rock dumps of the Granite Quarry Plant

the Kryvyi Rih area, there are various variants of rock prevalence (Manyuk, 2016; Savosko et al, 2018; Shvaiko \& Manyuk, 2017). Thus, in some cases, an extraordinary mosaic and chaotic pattern of soilforming rocks is observed (e.g. dumps, dams and different embankments).
However, on other devastated lands, even and uniform parent material are widespread (e.g. tailings and sludge storage). It was established that on devastated lands in the Kryvyi Rih Iron Mining \& Metallurgical District the initial pedogenesis is carried out on the following parent material (Table 1): 
1) iron quartzite (various geological composition and granulometric size), 2) loess loam (non-carbonate and carbonate), 3) shist (usually a large particle size - more than $100 \mathrm{~mm}$ ).In general, the parent materials on the devastated lands in the Kryvyi Rih area form different conditions for initial soil formation. Loess and loesslike loams, as well as loams and sandy loams from the sedimentary cover, are highly favourable to initial soil formation.

Vegetation. On the devastated lands in the Kryvyi Rih area, there are three main vegetation mentioned as follows: 1) grasses are dominant in the plant community, 2) vegetative communities have a syngenetic character, 3 ) type of vegetation determined by rocks. We have found that (Table 1) input of plant litter fall on these devastated lands varied from 100 $\mathrm{g}^{*} \mathrm{~m}^{-2 *} \mathrm{year}^{-1}$ to $600 \mathrm{~g}^{*} \mathrm{~m}^{-2 *} \mathrm{year}^{-1}$ (average values: 170-270 $\left.\mathrm{g}^{*} \mathrm{~m}^{-2 *} \mathrm{year}^{-1}\right)$. These values are 3-5 times less in comparison with the steppe ecosystem values. Also we established (Table 1) that input of fall of plant ash elements on these devastated lands varied from $7.50 \mathrm{~g}^{*} \mathrm{~m}^{-2 *} \mathrm{year}^{-1}$ to $22.10 \mathrm{~g}^{*} \mathrm{~m}^{-2 *}$ year $^{-1}$ (average

Table 1. Factors of soil formation on devastated lands in Kryvyi Rih Iron Mining \& Metallurgical District

\begin{tabular}{|c|c|c|c|c|c|}
\hline \multirow{3}{*}{ Devastated lands } & \multirow{3}{*}{ Parent material } & $\begin{array}{r}\text { Cha } \\
\text { of herbac }\end{array}$ & $\begin{array}{l}\text { ristics } \\
\text { vegetation }\end{array}$ & \multirow{3}{*}{ Topography } & \multirow{3}{*}{$\begin{array}{l}\text { Time, } \\
\text { years }\end{array}$} \\
\hline & & $\begin{array}{c}\text { Input } \\
\text { of plant } \\
\text { litter } \\
\text { fall }\end{array}$ & $\begin{array}{c}\text { Input } \\
\text { of plant } \\
\text { ash elements } \\
\text { fall }\end{array}$ & & \\
\hline & & \multicolumn{2}{|c|}{$\mathrm{g}^{*} \mathrm{~m}^{-2 *}$ year $^{-1}$} & & \\
\hline $\begin{array}{l}\text { Waste rock dumps } \\
\text { of old iron mines } \\
\text { (old name "Forges") }\end{array}$ & $\begin{array}{c}\text { Hydrohematite } \\
\text { iron quartzite }-90 \% \\
\text { Loess loam }-10 \%\end{array}$ & 250 & 14.2 & Dump plateau & $90-100$ \\
\hline \multirow{10}{*}{$\begin{array}{l}\text { Tailing storage } \\
\text { facility } \\
\text { of underground } \\
\text { iron mines }\end{array}$} & \multirow{2}{*}{ Hydrohematite iron quartzite } & 100 & 7.50 & Tailings beach & $50-55$ \\
\hline & & 230 & 17.1 & Tailings beach & $50-55$ \\
\hline & \multirow{4}{*}{$\begin{array}{l}\text { Martite \& hematite-martite } \\
\text { iron quartzite }\end{array}$} & 100 & 8.95 & Tailings beach & $30-35$ \\
\hline & & 150 & 12.8 & Tailings beach & $30-35$ \\
\hline & & 120 & 10.7 & Tailings beach & $30-35$ \\
\hline & & 140 & 12.1 & Tailings beach & $25-30$ \\
\hline & Loess loam & 160 & 10.4 & Tailings beach & $25-30$ \\
\hline & \multirow{3}{*}{$\begin{array}{l}\text { Martite \& hydrohematite } \\
\text { iron quartzite }\end{array}$} & 200 & 13.1 & Tailings beach & $40-45$ \\
\hline & & 180 & 12.9 & Tailings beach & $40-45$ \\
\hline & & 140 & 8.12 & Tailings beach & $40-45$ \\
\hline \multirow{5}{*}{$\begin{array}{l}\text { Waste rock dumps } \\
\text { of Iron Ore Mining } \\
\text { and Dressing Plant }\end{array}$} & Loess loam & 240 & 21.6 & Foot of dump & $55-60$ \\
\hline & $\begin{array}{l}\text { Poor magnetite } \\
\text { iron quartzite } 50 \% \\
\text { Loess loam } 50 \%\end{array}$ & 330 & 16.4 & Dump berm & $55-60$ \\
\hline & $\begin{array}{c}\text { Shist } 40-45 \%, \\
\text { Poor magnetite iron quartzite } \\
20-30 \%, \\
\text { Loess loam } 20-25 \%\end{array}$ & 380 & 21.3 & Dump berm & $40-45$ \\
\hline & $\begin{array}{c}\text { Shist } 45-50 \%, \\
\text { Poor magnetite } \\
\text { iron quartzite } 20-30 \%, \\
\text { Loess loam } 15-20 \% \\
\end{array}$ & 270 & 14.4 & Dump berm & $30-35$ \\
\hline & $\begin{array}{c}\text { Poor magnetite } \\
\text { iron quartzite } 60-70 \% \text {, } \\
\text { Shist } 10-20 \%, \\
\text { Loess loam } 5-10 \%\end{array}$ & 110 & 9.11 & Dump plateau & $25-20$ \\
\hline \multirow{2}{*}{$\begin{array}{c}\text { Waste rock dumps } \\
\text { of Granite Quarry } \\
\text { Plant }\end{array}$} & Loess loam & 420 & 22.1 & Dump plateau & $40-50$ \\
\hline & Carbonate loess loam & 380 & 18.8 & Dump plateau & $40-50$ \\
\hline
\end{tabular}

types. These vegetation types determine the main three soil formation strategies: petrophilic, woody and grassy plant community. The main vegetation features as a factor of initial soil formation can be values: $12-17 \mathrm{~g}^{*} \mathrm{~m}^{-2 *}$ year $\left.^{-1}\right)$.In general, the vegetation on the devastated lands in the Kryvyi Rih area form do not very strong or favourable conditions for initial soil formation. 
Climate. The Kryvyi Rih area is located in the semi-arid climate zone, called the northern steppe. The average annual precipitation is $450 \mathrm{~mm}$, concentrated between April and October. Average temperatures vary between $-6^{\circ} \mathrm{C}$ in January and $21^{\circ} \mathrm{C}$ in July. But on devastated lands of this region a special microclimate was formed. This microclimate naturally has an impact on initial soil formation. In most cases, this effect has a negative effect on soil formation: since there is an elevated temperature of the devastated land surface, which in turn drains the atmospheric air very much. But there is another opinion, as shown by studies by V.K. Tereshchenko (Tereshchenko, 1992), rocky rocks can condense moisture from the atmospheric air during darkness. As a result, their humidity significantly increases, which has a very positive effect on soil formation. In general, the microclimate on the devastated lands at Kryvyi Rih area forms very severe conditions for initial soil formation.

Topography. The unique mesorelief forms are an important feature of the devastated lands in the Kryvyi Rih area. In these territories, the main forms of mesorelief are: a smooth surface and microdepressions of the waste rock dumps berms, low hills $(1.0-1.5 \mathrm{~m})$ of the waste rock dumps, steep slopes of the waste rock dumps and a perfectly flat surface of the tailings pond beaches. It should also be noted that the exposure of the waste rock dumps slopes determines the redistribution of heat fluxes while micro-depressions and low hills determine the redistribution of water flows. By topography, the most favourable areas for initial soil formation are micro-depressions on berms and on the plateau of the waste rock dumps, as well as in the lower part of the slopes at waste rock dumps. It is here that the accumulation of precipitation occurs. On devastated lands of the Kryvyi Rih Iron Mining \& Metallurgical District, initial soil formation was investigated by us in the following topographies: 1) the foot of the dump, 2) dump berm, 3) dump plateau and 4) tailings beach (Table 1).In general, the topography of the devastated lands in the Kryvyi Rih area is an important factor that limits the success of initial soil formation.

Man. We believe that the primary and secondary effects of human activity on the initial soil formation on devastated lands should be distinguished. The primary effect of humans determined the geological and topographical "framework" on devastated lands. Therefore, this human influence predetermines the basic conditions for initial soil formation on devastated lands. The secondary human effect has a positive and negative impact on the initial soil formation in these areas. The positive secondary human impact is possible by the implementation of the restoration and reclamation of these lands. The negative secondary human impact is possible with air pollution and storage of garbage in these areas.

Time. In Kryvyi Rih region, the first devastated lands began to form in 1881. Due to archival materials and scientific publications, it is possible to assume the starting time of the soil formation with an accuracy of up to 5 years. This fact is very important for basic soil science. In general, the duration of soil formation on the devastated lands is known, and the soil is very young in these areas (table 1).

Chemical composition of young soils from devastated lands. The data in Table 2 indicate that the chemical and physical properties of young soils from devastated lands in the Kryvyi Rih Iron Mining \& Metallurgical District are characterized by unfavourable indicators. Thus organic matter content varied from $7.93 \%$ to $22.10 \%$ (on average - $9.10 \%-12.88 \%$ ). These values are 2.5-3.5 times lower than in the zonal soils of chernozems. It should also be noted that the accumulation of organic matter in the soil from the tailing storage facility of underground iron mines does not occur. This fact can be explained by the geological characteristics of the parent material materials, in particular, their grain size distribution.

In the zonal soils of the Kryvyi Rih Iron Mining \& Metallurgical District, soil acidity is 7.00-7.15 in ordinary chernozems and 7.25-7.55 in southern chernozems. But in soils from devastated lands these characteristics have higher values: for actual acidity - from 7.08 to 9.19 (on average - 8.18-8.81), for exchangeable acidity - - from 7.60 to 8.06 (on average -6.74-8.59). Thus, initial pedogenesis on devastated lands is carried out in very alkaline conditions. This fact significantly slows down the humus accumulation in the soil profile.

As is known, cation-exchange capacity (CEC) is a measure of how cations can be retained on soil particle surfaces. CEC is defined as the amount of positive charge that can be exchanged per mass of soil, usually measured in $\mathrm{mMol} / 100 \mathrm{~g}$ soil. In the zonal soils of the Kryvyi Rih Basin, CEC can obtain $35-40 \mathrm{mMol} / 100 \mathrm{~g}$ in ordinary chernozems and 30$35 \mathrm{mMol} / 100 \mathrm{~g}$ in southern chernozems. But in soils from devastated lands this characteristics is 2-20 times less, it varied from $2.01 \mathrm{mMol} / 100 \mathrm{~g}$ to 25.12 $\mathrm{mMol} / 100 \mathrm{~g}$ (on average $-5.62-10.18 \mathrm{mMol} / 100$ g). It is important to note that in natural soils $75-80 \%$ of CEC is calcium and, $15-25 \%$ is magnesium. As the results of our research show, in the young soils the 
share of calcium varied from $35.77 \%$ to $89.03 \%$ (on average $-56.16-71.81 \%$ ) and the magnesium portion varied from $10.97 \%$ to $64.23 \%$ (on average - 28.19 $43.84 \%$ ). In some soils, the amount of magnesium was greater in comparison with calcium.

Soil classification of the devastated land. Soil classification is a very important and very difficult task at the same time (Charzynski et al, 2013; Sere et al, 2010; Sobocka, 2008). At present, the introduction of the ideas and philosophy of World Reference Base for soil resources (WRB) in the classification of world soils is taking place. According to WRB, the soils on devastated lands in the Kryvyi Rih Iron Mining \& Metallurgical District can be classified as "Technosols" (WRB, 2015).

When specified, these soils are termed: 1) spolic technosol (ochric) on the waste rock dumps of the old iron mines (old name "Forges"), 2) spolic technosol (phytotoxic, arenic, aridic, magnesic) on the tailing storage facility of underground iron mines, 3) spolic technosol (humic, loamic, calcaric), spolic technosol (ochric, loamic) and spolic technosol (arenic, aridic, magnesic) on waste rock dumps of the Iron Ore Mining and Dressing Plant, 4) spolic technosol (ochric, loamic, dolomitic, calcaric) on waste rock dumps of the Granite Quarry.

In our opinion, the concept of embryozem and its groups is the most acceptable among the classification systems common in Ukraine for young soils on devastated lands. The word "embryozem" is formed by analogy with the word "chernozems" and means "young soil" (from Greek "ع $\mu \beta \rho v o v$, fetus or germ and from Ukrainian "zem", earth or soil).

In our opinion (Savosko, 2010; Savosko, 2011a), there are four groups of embryozems on devastated lands in the Kryvyi Rih Iron Mining \& Metallurgical District: Initial embryozems, organic-accumulative embryozems, turf embryozems and humusaccumulative embryozems. It should be noted that the basis of this differentiation is the intensity and quality of humus formation. This is naturally reflected in the structure of the soil profile. We believe that these young soils have the following distribution: 1) turf embryozems on the waste rock dumps of old iron mines (old name "Forges"), 2) initial embryozems on the tailing storage facility of underground iron mines, 3) initial embryozems, organic-accumulative embryozems and humus-accumulative embryozems on the waste rock dumps of the Iron Ore Mining and Dressing Plant, 4) turf embryozems on the waste rock dumps of the Granite Quarry.

Determination of initial pedogenesis on the devastated lands. An analysis of the mathematical calculations results showed that between factors of soil formation and chemical composition of the technosol from devastated lands in the Kryvyi Rih

Table 2. Chemical composition of the technosol from devastated lands at Kryvyi Rih Iron Mining \& Metallurgical District $(\mathrm{M} \pm \mathrm{m})$

\begin{tabular}{|c|c|c|c|c|c|c|}
\hline \multirow[b]{2}{*}{ Devastated lands } & \multirow{2}{*}{$\begin{array}{c}\text { Organic matter } \\
\text { content, } \%\end{array}$} & \multicolumn{2}{|c|}{$\mathrm{pH}$} & \multicolumn{3}{|c|}{ Cation-exchange capacity } \\
\hline & & $\mathrm{pH}_{\mathrm{H} 2 \mathrm{O}}$ & $\mathrm{pH}_{\mathrm{KCl}}$ & $\begin{array}{c}\text { Total, } \\
\mathrm{mMol} / 100 \mathrm{~g}\end{array}$ & $\begin{array}{c}\mathrm{Ca}, \\
\% \text { from total }\end{array}$ & $\begin{array}{c}\mathrm{Mg}, \\
\% \text { from total }\end{array}$ \\
\hline $\begin{array}{l}\text { Waste rock dumps } \\
\text { of old Iron Mines } \\
\text { (old name "Forges") }\end{array}$ & $9.97 \pm 1.05$ & $7.58 \pm 0.01$ & $6.74 \pm 0.02$ & $6.62 \pm 0.26$ & 59.67 & 40.33 \\
\hline \multirow{10}{*}{$\begin{array}{c}\text { Tailing storage facility } \\
\text { of Underground } \\
\text { Iron Mines }\end{array}$} & - & $8.81 \pm 0.02$ & $8.10 \pm 0.01$ & $7.80 \pm 0.35$ & 85.88 & 14.12 \\
\hline & - & $8.79 \pm 0.01$ & $8.09 \pm 0.02$ & $7.93+0.32$ & 89.03 & 10.97 \\
\hline & - & $8.92 \pm 0.01$ & $7.92 \pm 0.01$ & $8.47 \pm 0.38$ & 88.55 & 11.45 \\
\hline & - & $9.01 \pm 0.01$ & $8.23 \pm 0.02$ & $7.00 \pm 0.31$ & 83,86 & 16.14 \\
\hline & - & $9.14 \pm 0.02$ & $8.23 \pm 0.01$ & $6.34 \pm 0.21$ & 73.66 & 26.34 \\
\hline & - & $9.19 \pm 0.01$ & $8.59 \pm 0.02$ & $6.00 \pm 0.19$ & 62.17 & 37.83 \\
\hline & - & $8.90 \pm 0.01$ & $8.38+0.01$ & $6.74 \pm 0.25$ & 60.39 & 39.61 \\
\hline & - & $7.72 \pm 0.01$ & $8.06 \pm 0,02$ & $2.60 \pm 0.13$ & 35.77 & 64.23 \\
\hline & - & $7.51 \pm 0.02$ & $7.64 \pm 0.01$ & $2.06 \pm 0.11$ & 54.85 & 45.15 \\
\hline & - & $8.82 \pm 0.01$ & $8.34+0.02$ & $4.14+0.19$ & 45.17 & 54.83 \\
\hline \multirow{6}{*}{$\begin{array}{l}\text { Waste rock dumps } \\
\text { of Iron Ore Mining } \\
\text { and Dressing Plant }\end{array}$} & $16.20 \pm 0.89$ & $8.83 \pm 0.01$ & $7.88 \pm 0.01$ & $25.12 \pm 1.25$ & 52.75 & 47.25 \\
\hline & $11.16+0.86$ & $8.51 \pm 0.02$ & $7.35 \pm 0.02$ & $6.66 \pm 0.20$ & 68.32 & 31.68 \\
\hline & $12.85+1.02$ & $8.08+0.01$ & $7.22+0.04$ & $9.57 \pm 0.38$ & 56.53 & 43.47 \\
\hline & $9.53 \pm 0.78$ & $7.66 \pm 0.02$ & $7.49 \pm 0.01$ & $9.14 \pm 0.39$ & 53.06 & 46.94 \\
\hline & $8.75+0.99$ & $8.57 \pm 0.01$ & $7.79 \pm 0.01$ & $11.56+0.42$ & 49.05 & 50.95 \\
\hline & $7.93 \pm 1.11$ & $8.45 \pm 0.01$ & $7.99 \pm 0.01$ & $7.72 \pm 0.23$ & 43.91 & 56.09 \\
\hline \multirow{2}{*}{$\begin{array}{c}\text { Waste rock dumps } \\
\text { of Granite Quarry } \\
\text { Plant }\end{array}$} & $11.44 \pm 1.14$ & $8.72 \pm 0.02$ & $7.42 \pm 0.02$ & $7.42 \pm 0.27$ & 73.58 & 26.42 \\
\hline & $11.09 \pm 1.19$ & $9.18 \pm 0.02$ & $7.35 \pm 0.02$ & $7.30 \pm 0.25$ & 79.45 & 20.55 \\
\hline
\end{tabular}

$\mathrm{M}$ - arithmetic mean (average), $\mathrm{m}-$ mean absolute error, «-»- organic matter is absent in the roots soil layer $(0-20 \mathrm{~cm})$ 
Iron Mining \& Metallurgical District statistically significant correlation dependence was established (Table 3). Thus 8 coefficients (from 18 theoretically possible) were statistically significant $(\mathrm{P}<0.05)$. Among these coefficients, 4 (50\%) were greater than $0(r>0)$ and indicated a positive relationship between two phenomena (values of two variables changing with same direction). While the other 4 (50\%)
Conclusions. In the devastated lands at Kryvyi Rih Iron Mining \& Metallurgical District (Ukraine), the initial soil formation occurs under very severe and difficult conditions. Parent material is very unfavourable for the vegetation's development. Therefore, the vegetation cover is fragmentary and is characterized by very insignificant values of plant litter fall and of input of plant ash elements fall. During 25-

Table 3. Pearson Correlation between factors of soil formation and chemical composition of the technosol on devastated lands of the Kryvyi Rih Iron Mining \& Metallurgical District

\begin{tabular}{|c|c|c|c|c|}
\hline \multirow{4}{*}{\multicolumn{2}{|c|}{ Chemical composition of the technosol }} & \multicolumn{3}{|c|}{ Factors of soil formation } \\
\hline & & \multirow{3}{*}{ Time, years } & \multicolumn{2}{|c|}{$\begin{array}{c}\text { Characteristics } \\
\text { of herbaceous vegetation }\end{array}$} \\
\hline & & & $\begin{array}{l}\text { Input of plant } \\
\text { litter fall }\end{array}$ & $\begin{array}{l}\text { Input of plant ash } \\
\text { elements fall }\end{array}$ \\
\hline & & & \multicolumn{2}{|c|}{$\mathrm{g}^{*} \mathrm{~m}^{-2 *}$ year $^{-1}$} \\
\hline \multicolumn{2}{|c|}{ Organic matter content, $\%$} & $0.461 *$ & $0.643 * *$ & $0.662 * *$ \\
\hline \multirow{2}{*}{$\mathrm{pH}$} & $\mathrm{pH}_{\mathrm{H} 2 \mathrm{O}}$ & $-0.382 *$ & -0.112 & -0.089 \\
\hline & $\mathrm{pH}_{\mathrm{KCl}}$ & $-0.719 * * *$ & $-0.568 * *$ & $-0.474 *$ \\
\hline \multirow{3}{*}{$\begin{array}{l}\text { Cation- } \\
\text { exchange } \\
\text { capacity }\end{array}$} & Total, mMol /100 g & 0.173 & 0.161 & $0.453^{*}$ \\
\hline & $\mathrm{Ca}, \%$ from total & 0.061 & 0.001 & 0.018 \\
\hline & $\mathrm{Mg}, \%$ from total & -0.061 & 0.001 & -0.019 \\
\hline
\end{tabular}

* - level of statistical significance $\mathrm{P}<0.05$; ** - level of statistical significance $\mathrm{P}<0.01$;

$* * *$ - level of statistical significance $\mathrm{P}<0.001$

coefficients were less than $0(r<0)$ and indicated a negative relationship between two phenomena (the values of variables change with opposite direction).

The numerical values of correlation coefficients analysis established the following patterns for degree of correlation: 4 correlation coefficients indicate a weak degree of relationship between phenomena $(0.3<|\mathrm{r}|<0.5) ; 3$ correlation coefficients indicate a moderate degree of relationship between phenomena $(0.5<|\mathrm{r}|<0.7) ; 1$ correlation coefficients indicate a strong degree of relationship between phenomena $(|\mathrm{r}|>0.7)$. Among factors of soil formation time (duration of soil formation) and input of plant ash elements fall are characterized by the maximum number of statistically significant correlation coefficients and their numerical values. While another factor of soil formation (input of plant litter fall) is characterized by lower numerical values and approximately the same number of statistically significant correlation coefficients and their numerical values. Among chemical composition of the technosol, the values of organic matter content and exchangeable acidity $\left(\mathrm{pH}_{\mathrm{KCl}}\right)$ were the most predictable by chemical composition of the technosol.
100 years only very primitive soils were formed. For these soils the following features are characteristic: (1) unformed soil profile (only thickness 10-100 $\mathrm{mm}$ ), (2) low levels of organic substance content, (3) alkaline indicators of the soil solution, (4) low levels of cation exchange capacity. According to the World Reference Base for Soil Resources (WRB, 2015), young soils in the devastated lands can be classified as spolic technosol with different supplementary qualifiers such as arenic, aridic, calcaric, dolomitic, humic, loamic, magnesic, ochric, phytotoxic. However, according to the Ukrainian young soils' classification system, these soils can be classified as embryozems which are represented by: (1) initial embryozems, (2) turf embryozems, (3) organicaccumulative embryozems, (4) humus-accumulative embryozems. Among factors of soil formation, time and input of plant ash elements' fall are characterized by the maximum number of statistically significant correlation coefficients and their numerical values. In chemical composition, the values of organic matter content and exchangeable acidity $\left(\mathrm{pH}_{\mathrm{KCl}}\right)$ were the most predictable soil formation factors. 


\section{References}

Antrop, M. (2006). Sustainable landscapes: contradiction, fiction or utopia? Landscape and Urban Planning, 75, 187-197.

Aronson, J., \& Alexander, S. (2013). Ecosystem Restoration is Now a Global Priority: Time to Roll up our Sleeves. Restoration Ecology, 21, 3, 293-296. DOI: $10.1111 /$ rec.12011.

Berger, A., Brown, C., Kousky, C., \& Zeckhauser, R. (2011). The Challenge of Degraded Environments: How Common Biases Impair Effective Policy. Risk Analyses, 31 (9), DOI: 10.1111/j.15396924.2010.01477.x

Breemen, N. van, \& Buurman, P. (2003). Soil Formation. Kluwer Academic Publishers, New York.

Charzynski, P. (ed.), P. Hulisz (ed.), \& R. Bednarek (ed). (2013). Technogenic soils of Poland. Polish Society of Soil Science, Torun.

Cortina-Segarra, J., Decleer, K., \& Kollmann, J. (2016). Speed restoration of EU ecosystems. Nature, 535, 231.

Demidov, A. A., Kobets A. S., Gritsan Yu. I., \& Zhukov A. V. (2013). Prostranstvennaya agroekologiya i rekultivatsiya zemel [Spatial agroecology and reclamation of land]. Dnipropetrovsk, Publishing House «Svidler AL». (in Russian).

DSTU-ISO 10381-8:2006. Soil quality, Sampling, Part 8 Guidance on sampling of stockpiles. DSTU-ISO 10390:2001. Soil quality, Determination of $\mathrm{pH}$.

DSTU-ISO 10694-2001. Soil quality, Determination of organic and total carbon after dry combustion (elementary analysis).

DSTU-ISO 11260:2001. Soil quality - Determination of exchangeable acidity in barium chloride extracts (ISO 14254:2001).

DSTU-ISO 11664:2006. Soil quality, Pretreatment o samples for physic-chemical analyses.

Hlava, J., Hlavová, A., Hakl, J., \& Fer, M. (2015). Earthworm responses to different reclamation processes in post opencast mining lands during succession. Environ Monitoring Assessment, 187, 4108. DOI: $10.1007 / \mathrm{s} 10661-014-4108-8$.

Jenny, H. (1994). Factors of soil formation a System of Quantitative Pedology. Dover publications, New York.

Kumar, B. M. (2013). Mining waste contaminated lands: an uphill battle for improving crop productivity. Journal of Degraded and Mining Lands Management, 1, 1, 43-50.

Lakin, G. F. (1990). Biometriya [Biometrics]. Moscow, Vyisshaya shkola. (in Russian).

Lykholat, Y., Alekseeva, A., Khromykh, N., Ivanko, I., Kharytonov, M., \& Kovalenko, I. (2016a). Assessment and prediction of viability and metabolic activity of Tilia platyphyllos in arid steppe climate of Ukraine. Agriculture and Forestry. Podgorica, 62 (3), 65-71.

Lykholat, Y., Khromyk, N., Ivanko, I., Kovalenko, I.,
Shupranova, L., \& Kharytonov, M. (2016b). Metabolic responses of steppe forest trees to altitude associated local environmental changes. Agriculture \& Forestry. Podgorica, 62 (2), 163171.

Malahov, I. N. (2009). Novaya geologicheskaya sila (Geologicheskaya sreda antropogennoy ekosistemyi) [New geological force (Geological environment of anthropogenic ecosystem)]. Kryvyi Rih, Publishing House «Ukraine» (in Russian).

Malaxov, I. M. (2003). Texnohenez u heolohičnomu seredovyšči [Technogenesis in the geological environment]. Kryvyj Rih: Oktant-Print. (in Ukrainian).

Manyuk, V. V., (2016). Geological heritage as an integral part of the Nature Reserve Lands of Kharkiv oblast Dnipropetrovsk University Bulletin. Series Geology, Geography, 24 (1), 71-82. DOI: 10.15421/111611. (in Ukrainian).

Mazur, A. Ye., Kucherevskyi, V. V., Shol', H. N., Baranets, M. O., Sirenko, T. V., \& Krasnoshtan, O. V. (2015). Biotekhnolohiia rekultyvatsii zalizorudnykh vidvaliv shliakhom stvorennia stiikykh travianystykh roslynnykh uhrupovan [Biotechnology of iron-ore dump recultivation by creation of stable plant communities]. Nauka ta inovatsii [Science and Innovations], 11 (4), 4152. DOI:10.15407/scin11.04.041. (in Ukrainian).

MCdonald, J.H. (2014). Handbook of biolological statistics. Sparky house publishing, Baltimore.

Resulović, H., \& Čustović, H. (2007). Technosols - Development, Classification and Use. Agriculturae Conspectus Scientificus, 72, 1, 1316.

Savosko, V. M. (2010). Genezis i morfologiya primitivnyih pochv tehnogennyih landshaftov Krivbassa [Genesis and morphology of the primitive soils in technological landscapes at Kryvbas]. Pytannia bioindykatsii ta ekolohii [Bioindication and Ecology Questions], 15 (2), 152-162. (in Russian).

Savosko, V. M., Nevyadomsky, M. A., \& Kudriava, P. Y. (2010). Fiziko-himicheskie svoystva substratov shahtnyih hvostohranilisch Krivbassa [The physical and chemical properties of substrates at mine tailing ponds at kryvbas]. Pytannia bioindykatsii ta ekolohii [Bioindication and Ecology Questions], 15 (1), 88-89. (in Russian).

Savosko, V. M. (2011a). Melioraciya ta fitorekultyvaciya zemel [Land melioration and phtoyreclamation]. Kryvyj Rih, Dionis. (in Ukrainian).

Savosko, V. M. (2011b) Otsinka fitotoksychnosti substrativ shakhtnykh khvostoskhovyshch Kryvorizhzhia [The estimation of phytotoxicity of substrate at mine tailing ponds in the Kryvyi Rih iron-ore region]. Promyslova botanika [Industrial Botany], 11, C. 19-25. (in Ukrainian).

Savosko, V. M., \& Tovstolyak, N. V. (2017). Ecological 
conditions of garden and park territories of former iron mines (Kryvyi Rih Basin, Ukraine). Ukrainian Journal of Ecology, 7 (4), 12-17. (in Ukrainian).

Savosko, V., Lykholat, Yu., Domshyna, K., \& Lykholat, T. (2018). Ekolohichna ta heolohichna zumovlenist poshyrennia derev i chaharnykiv na devastovanykh zemliakh Kryvorizhzhia [Ecological and geological determination of dispersal of trees and shrubs on the devastated lands in Kryvorizhya]. Journal of Geology, Geography and Geoecology, 27 (1), 116-130. DOI: $10.15421 / 111837$. (in Ukraine).

Sere, G., Schwartz, Ch., Ouvrard, S., Renat, J.-Ch., Watteau, F., Villemin, G., \& Morel, J.L. (2010). Early pedogenic evolution of constructed Technosols. Journal of Soils and Sediments, 10, 1246-1254. DOI 10.1007/s11368-010-0206-6.

Shvaiko, V. M., \& Manyuk, V. V. (2017). The Ecological Network of the subregional level ofDnipropetrovsk region (Pokrovsky and Mezhyvsky districts).
Dnipropetrovsk University Bulletin. Series: Geology, Geography. 25 (1), 2017, 119-130. DOI: 10.15421/111. (in Ukraine).

Sobocka, J. (2008). Position of technosols in the Slovak soil classification system and their correlation. Gruntoznavstvo [Soil science], 9, 3-4, 177-182.

Tereschenko, V. F. (1992). Ekologicheskie printsipyi i priemyi podbora drevesnyih i kustarnikovyih porod dlya rekultivatsii skalnyih otvalov Krivbassa [Ecological principles and methods of selection of wood and shrub species for recultivation of rock dumps in Kryvbass]. Abstract of Thesis for Candidate of Sciences degree in Biology. Dnipropetrovsk, Dnipropetrovsk State University, (in Russian).

World reference base for soil resources (2015). International soil classification system for naming soils and creating legends for soil maps. Food and agriculture organization of the United Nations, Rome. 